\title{
THE ANEMIA OF INFECTION. VII. THE SIGNIFICANCE OF FREE ERYTHROCYTE PROTOPORPHYRIN, TOGETHER WITH SOME OBSERVATIONS ON THE MEANING OF THE "EASILY SPLIT-OFF" IRON ${ }^{1}$
}

\author{
By M. GRINSTEIN,² JOSÉ A. SILVA,3 ANd MAXWELL M. WINTROBE \\ (From the Department of Medicine, School of Medicine, University of Utah, Salt Lake City)
}

(Received for publication September 8, 1947)

Studies in this laboratory (1) on the anemia accompanying infection have indicated that there is associated with such anemia a disturbance in the metabolism of porphyrins. The amount of free protoporphyrin in the erythrocytes has been found to be increased and the excretion of coproporphyrin in the urine is greater than normal. The present report deals with studies designed to investigate the significance of the free protoporphyrin in the erythrocytes.

The presence of free protoporphyrin in the erythrocytes (EP) was reported in 1928 by van den Bergh and Hyman (2). Grotepass (3) and subsequently Watson, Grinstein and Hawkinson (4) demonstrated that the free protoporphyrin in erythrocytes is identical with the protoporphyrin in hemoglobin; namely, protoporphyrin 9, type III. Seggel (5) concluded that the protoporphyrin resides in erythrocytes which exhibit red fluorescence in ultraviolet light. He named such cells fluorescytes and regarded them as being either reticulocytes or adult erythrocytes containing porphyrin. Seggel suggested that free protoporphyrin represents an intermediate compound in the synthesis of hemoglobin. He presented evidence that the fluorescytes are increased as a result of iron deficiency or as a consequence of other disturbances of hemoglobin synthesis (5).

Watson and Clarke (6) observed upon centrifuging different samples of blood that the upper layer of the packed cells, which is richer in reticulocytes, showed a much higher content of proto-

1 This study was carried out under a grant from the United States Public Health Service and was also supported by grants from the Upjohn Company and Parke, Davis and Company.

2 On leave from the University of Cordoba, Cordoba, Argentina.

${ }^{3}$ Fellow of the Rockefeller Foundation, on leave from the Department of Medicine, College of Medicine, University of the Philippines, Manila, Philippines. porphyrin than the lower layer. They concluded that the protoporphyrin resides mainly in the reticulocytes. Similar conclusions were reached later by DeLangen and Grotepass (7). Further studies by Watson and his associates $(4,8)$ showed, however, that although there is frequently a close parallelism between the increase in protoporphyrin and normoblastic activity, as measured by the percentage of the reticulocytes, several other factors influence the protoporphyrin content of the erythrocytes. These are $(a)$ the presence of iron deficiency or of factors interfering with the utilization of iron in the synthesis of hemoglobin as, for example, lead poisoning ; and $(b)$ the presence of conditions which permit the formation of protoporphyrin by degradation of hemoglobin in intact erythrocytes. The formation of protoporphyrin from hemoglobin in intact erythrocytes would be a simple explanation of the increase observed after incubation of blood in vitro (4). Czike (9), Barkan and Walker (10), and Watson and Paine (11) have presented evidence indicating that hemoglobin breakdown can take place inside the intact red cell. According to the last two groups of workers, this is through the formation of pseudohemoglobin (Barkan) or verdohemoglobin (Lemberg). From studies mainly carried out by Barkan and Schales (12) and Lemberg et al. $(13,14)$ it would seem that the non-hemoglobin iron of the erythrocytes which is easily ionized by the incubation of blood in 0.4 per cent $\mathrm{HCl}$ for 16 to 24 hours is part of a bile pigmentiron-native globin complex similar to or identical with the pseudohemoglobin of Barkan or the verdohemoglobin of Lemberg. According to Barkan this iron, known as "easily split-off iron" (ESFe), corresponds to about 5 per cent of the total hemoglobin iron found in human beings. Lemberg (13) claims that two-thirds of the $\mathrm{ESFe}$ is an artefact due to the oxidation of the 
prosthetic group of the hemoglobin by the oxygen evolved from oxyhemoglobin by acids.

An increase in free erythrocyte protoporphyrin has been found in cases associated with hemolytic anemia (8). In such cases one would wonder whether some of the increase may be due to protoporphyrin formed in the cells as a degradation product. Nevertheless, since in most instances of hemolytic anemia an increase in reticulocytes occurs, the possibility arises that the increase in EP is related to a high percentage of young cells rather than due to the degradation that may take place in the mature cells.

In an attempt to seek further information concerning the significance of EP, it was decided to measure the free EP of erythrocytes under various experimental conditions and to calculate the average free protoporphyrin of mature cells and reticulocytes. At the same time, since the results of several authors (15 to 17 ) raise the question whether ESFe is a labile hemoglobin iron or just an artefact, the opportunity was taken in the experiments presented here to secure some data which might throw light on the significance of the ESFe.

\section{METHODS AND CALCULATIONS}

When the blood is centrifuged the reticulocytes, being lighter than mature cells, remain in the upper part of the packed cells (18). In order to secure concentrated specimens of reticulocytes and of mature cells, after separating the plasma, the column of packed cells of various samples of blood was divided into three equal parts: the upper (u) and lower (1) parts were then suspended separately in 0.9 per cent $\mathrm{NaCl}$ to approximate the original volume. In both fractions the reticulocyte percentage was determined by the brilliant cresyl blue wet stain method (19). The middle portion was discarded. We have found (Table I) that in suspending rabbits' cells

TABLE I

Showing that suspending red cells in 0.9 per cent saline solution has no effect on the mean corpuscular volume ( $M C V)$

\begin{tabular}{l|c|c||c|c|c}
\hline \hline \multicolumn{3}{c||}{ Whole blood } & \multicolumn{3}{c}{$\begin{array}{c}\text { After suspension in } \\
\text { 0.9\% NaCl soln. }\end{array}$} \\
\hline RBC & Ht & MCV & RBC & Ht & MCV \\
\hline 4.19 & 34.0 & 81 & 4.26 & 34.4 & 81 \\
4.13 & 35.1 & 83 & 4.45 & 37.0 & 82 \\
4.31 & 34.0 & 79 & 4.45 & 33.5 & 76 \\
4.52 & 34.0 & 75 & 4.57 & 33.5 & 73 \\
5.56 & 41.0 & 74 & 5.10 & 41.5 & 81 \\
5.03 & 35.0 & 69 & 4.99 & 36.0 & 72 \\
\hline
\end{tabular}

in 0.9 per cent saline, the mean corpuscular volume (MCV) remains unchanged. By determining the percentage of the reticulocytes and mature cells in each fraction, the following three systems of equations could be established:

1. $\frac{100-a}{100} X+\frac{a}{100} Y=\mathrm{MCV}$ of the upper fraction

$$
\frac{100-b}{100} X+\frac{b}{100} Y=\mathrm{MCV} \text { of the lower fraction, }
$$

when

$a$ is the reticulocyte percentage of the upper fraction;

$b$ is the reticulocyte percentage of the lower fraction;

$X$ is the mean corpuscular volume of the mature erythrocytes $\left(M_{C V}\right)$; and

$Y$ is the mean corpuscular volume of the reticulocytes $\left(\mathrm{MCV}_{\mathbf{R}}\right)$.

$$
\text { 2. } \begin{aligned}
\frac{100-a}{100} X+\frac{a}{100} Y & =P_{u} \\
\frac{100-b}{100} X+\frac{b}{100} Y & =P_{l} \text {, when }
\end{aligned}
$$

$P_{*}$ is the free protoporphyrin of the upper fraction expressed in micrograms per $1,000 \mathrm{ml}$. of packed cells;

$P_{l}$ is the free protoporphyrin of the lower fraction expressed in micrograms per $1,000 \mathrm{ml}$. of packed cells;

$X$ is the free protoporphyrin per $1,000 \mathrm{ml}$. of packed mature erythrocytes expressed in micrograms $\left(P_{x}\right)$; and

$Y$ is the free protoporphyrin per $1,000 \mathrm{ml}$. of packed reticulocytes expressed in micrograms $\left(P_{R}\right)$.

If the concentration of the protoporphyrin per 1,000 $\mathrm{ml} .\left(10^{15} \mu^{3}\right)$ of packed mature cells and reticulocytes is known, the mean content of free erythrocyte protoporphyrin in the mature red cells (MEP) and the mean reticulocyte free protoporphyrin (MRP) can be calculated by the following equations:

$$
\begin{aligned}
& \text { MEP }=\frac{P_{\mathrm{I}} \times M C V_{\mathrm{B}}}{10^{15}} \\
& M R P=\frac{P_{\mathrm{B}} \times M C V_{\mathrm{E}}}{10^{15}} .
\end{aligned}
$$

The values for MEP and MRP are expressed in micromicromicrograms [ $\left.\left(10^{-18}\right) \mathrm{gm}.\right]$.

$$
\text { 3. } \begin{aligned}
\frac{100-a}{100} X+\frac{a}{100} Y & =\mathrm{ESFe}_{u} \text { (per cent) } \\
\frac{100-b}{100} X+\frac{b}{100} Y & =\mathrm{ESFe}_{1} \text { (per cent), when }
\end{aligned}
$$

$\mathrm{ESFe}_{\mathrm{u}}$ is the "easily split-off" iron of the upper fraction expressed in proportion to the total hemoglobin iron;

$\mathrm{ESFe}_{1}$ is the "easily split-off iron of the lower fraction expressed in proportion to the total hemoglobin iron;

$X$ is the "easily split-off" iron of the mature erythrocytes expressed in relation to the total hemoglobin iron $\left(\mathrm{ESFe}_{\mathrm{x}}\right)$;

$Y$ is the "easily split-off" iron of the reticulocytes expressed in relation to the total hemoglobin iron (ESFer). 
The following determinations were run on the whole (w) blood as well as on the upper (u) and lower (1) fractions: red blood cell counts using the bright line Spencer counting chamber and a standardized red cell pipette; volume of packed cells, using the Wintrobe hematocrit tube; hemoglobin, by the photoelectric oxyhemoglobin method, using an Evelyn photoelectric colorimeter. The instrument was standardized by the Van Slyke procedure as well as by the hemin method of Clegg and King (20). The fragility of the red cells was measured by the photoelectric method of Hunter (21). The number of determinations was limited, however, by using only 0.78 per cent saline for dilution of the blood and measuring the hemoglobin concentration of the supernatant fluid.

Plasma iron was determined by the method of Barkan and Walker (22) but twice the quantities recommended by them were used. Plasma bilirubin was determined by the method of Ducci and Watson (23). "Easily splitoff" iron was measured by the method of Barkan and Walker (22) with the following modification: one $\mathrm{ml}$. of whole blood was centrifuged, the plasma removed and the cells hemolyzed with iron-free water, the volume being finally made up to $5 \mathrm{ml}$. One $\mathrm{ml}$. of the upper and lower fractions of the blood was treated in exactly the same way and made up to a volume of $5 \mathrm{ml}$. It was decided not to centrifuge and discard the supernatant fluid because this would permit loss of a significant frac- tion of the ESFe, since Barkan (24) showed that the more fragile cells contain more ESFe. To the $5 \mathrm{ml}$. of hemolyzed cells, $2.5 \mathrm{ml}$. of 1.2 per cent of $\mathrm{HCl}$ was added and incubated for 16 to 24 hours. The remaining steps of the procedure as outlined by Barkan were then followed without modification.

Free erythrocyte protoporphyrin (EP) was determined by a modification of the method of Grinstein and Watson (25) measuring the absorption exactly at the wave length of maximum absorption $(411 \mathrm{~m} \mu)$ of the protoporphyrin in 25 per cent $\mathrm{HCl}$. The Beckman spectrophotometer was used. With this apparatus the sensitivity of the method is increased about five times. The details of the modified method requiring only 2 to $3 \mathrm{ml}$. of blood will be described elsewhere (26).

The measurements which have been described and the calculations derived therefrom were carried out in the following experiments.

\section{Phenylhydrazine hemolytic anemia in rabbits:}

Hemolytic anemia was produced in rabbits by injecting intraperitoneally a 5 per cent solution of phenylhydrazine hydrochloride. According to the size and age of the rabbits, from 50 to $150 \mathrm{mgm}$. were injected. Blood samples were taken by cardiac puncture at appropriate intervals before and after the drug was given.

TABLE II

Changes observed in a rabbit following injection of phenylhydrazine

\begin{tabular}{|c|c|c|c|c|c|c|c|c|c|c|c|c|}
\hline Date & Blood* & $\mathbf{R B C}$ & $\mathbf{H b}$ & $\mathbf{H t}$ & $\mathrm{MCV}$ & MCH & мснс & Retic. & EP & Bil. & Pl. Fe. & ESFe \\
\hline $1 / 27$ & w & $\begin{array}{c}\text { mill./c. } \\
\text { mm. } \\
6.10\end{array}$ & $\begin{array}{c}\mathrm{gm./100} \\
\mathrm{ml.} \\
13.95\end{array}$ & $\begin{array}{c}m l . / 100 \\
m l . \\
40.8\end{array}$ & $\begin{array}{c}c . \mu . \\
67\end{array}$ & $\begin{array}{l}\gamma \gamma \\
23\end{array}$ & $\begin{array}{l}\% \\
34\end{array}$ & $\begin{array}{l}\% \\
4.6\end{array}$ & $\begin{array}{c}\gamma / 100 \\
m ! \cdot R B C \\
63\end{array}$ & $\begin{array}{l}\text { mgm. } \\
0.19\end{array}$ & $\begin{array}{c}\gamma / 100 \\
m l . p l . \\
178\end{array}$ & $\begin{array}{c}\%_{\text {iron }} \text { ob } \\
3.55\end{array}$ \\
\hline $1 / 27$ & & & & mgm. of & phenyll & ydrazine & $\mathrm{HCl}$ injec & ed intra & peritonea & & & \\
\hline $1 / 28$ & $\begin{array}{l}\mathbf{w} \\
\mathbf{u} \\
1\end{array}$ & $\begin{array}{l}3.90 \\
3.65 \\
3.55\end{array}$ & $\begin{array}{r}10.39 \\
11.40 \\
8.38\end{array}$ & $\begin{array}{l}28.0 \\
38.0 \\
22.0\end{array}$ & $\begin{array}{l}72 \\
85 \\
62\end{array}$ & $\begin{array}{l}27 \\
31 \\
24\end{array}$ & $\begin{array}{l}37 \\
37 \\
38\end{array}$ & $\begin{array}{l}28.9 \\
43.5 \\
12.6\end{array}$ & $\begin{array}{l}205 \\
259 \\
208\end{array}$ & $\frac{0.16}{=}$ & $\frac{242}{-}$ & $\begin{array}{l}4.90 \\
4.66 \\
5.88\end{array}$ \\
\hline $1 / 29$ & $\mathbf{w}$ & 2.59 & 6.90 & 19.5 & 75 & 27 & 35 & 39.4 & 230 & 0.16 & 317 & 3.91 \\
\hline $1 / 30$ & $\begin{array}{l}w \\
u \\
1\end{array}$ & $\begin{array}{l}2.31 \\
2.19 \\
2.73\end{array}$ & $\begin{array}{l}6.41 \\
6.06 \\
7.84\end{array}$ & $\begin{array}{l}19.0 \\
21.0 \\
20.0\end{array}$ & $\begin{array}{l}82 \\
96 \\
73\end{array}$ & $\begin{array}{l}28 \\
28 \\
30\end{array}$ & $\begin{array}{l}34 \\
29 \\
39\end{array}$ & $\begin{array}{r}45.6 \\
63.4 \\
6.8\end{array}$ & $\begin{array}{l}485 \\
746 \\
237\end{array}$ & $\begin{array}{l}0.16 \\
-\end{array}$ & $\frac{362}{-}$ & $\begin{array}{l}3.58 \\
2.81 \\
4.35\end{array}$ \\
\hline $1 / 31$ & $\mathbf{w}$ & 2.03 & 5.48 & 18.2 & 91 & 27 & 30 & 57.2 & 205 & 0.13 & 530 & 3.13 \\
\hline $2 / 3$ & $\begin{array}{l}\mathbf{w} \\
\mathbf{u} \\
1\end{array}$ & $\begin{array}{l}3.14 \\
3.22 \\
3.41\end{array}$ & $\begin{array}{l}8.71 \\
8.64 \\
7.55\end{array}$ & $\begin{array}{l}33.0 \\
36.2 \\
29.1\end{array}$ & $\begin{array}{r}105 \\
112 \\
85\end{array}$ & $\begin{array}{l}28 \\
27 \\
22\end{array}$ & $\begin{array}{l}26 \\
24 \\
26\end{array}$ & $\begin{array}{l}42.4 \\
60.1 \\
23.2\end{array}$ & $\begin{array}{l}253 \\
294 \\
207\end{array}$ & $\stackrel{0.13}{=}$ & $\underline{143}$ & $\begin{array}{l}2.74 \\
3.07 \\
3.68\end{array}$ \\
\hline $2 / 7$ & $\begin{array}{l}\mathbf{w} \\
\mathbf{u} \\
\mathbf{l}\end{array}$ & $\begin{array}{l}4.30 \\
4.42 \\
3.97\end{array}$ & $\begin{array}{r}10.27 \\
10.52 \\
9.57\end{array}$ & $\begin{array}{l}37.8 \\
40.5 \\
33.3\end{array}$ & $\begin{array}{l}88 \\
92 \\
84\end{array}$ & $\begin{array}{l}24 \\
24 \\
24\end{array}$ & $\begin{array}{l}27 \\
26 \\
28\end{array}$ & $\begin{array}{l}18.6 \\
46.6 \\
11.6\end{array}$ & $\begin{array}{r}98 \\
109 \\
92\end{array}$ & $\frac{0.12}{-}$ & $\frac{217}{-}$ & $\begin{array}{l}3.52 \\
3.98 \\
3.60\end{array}$ \\
\hline \multirow{2}{*}{\multicolumn{3}{|c|}{ Calculated data: }} & Date & \multicolumn{2}{|c|}{ MCVE } & MCVR & \multicolumn{2}{|c|}{ PE } & PR & \multicolumn{2}{|c|}{ MEP } & MRP \\
\hline & & & $\begin{array}{l}1 / 28 \\
1 / 30 \\
2 / 3 \\
2 / 7\end{array}$ & \multicolumn{2}{|c|}{$\begin{array}{l}53 \\
70 \\
68 \\
82\end{array}$} & $\begin{array}{l}127 \\
111 \\
141 \\
100\end{array}$ & \multicolumn{2}{|c|}{$\begin{array}{r}188 \\
177 \\
152 \\
87\end{array}$} & $\begin{array}{r}352 \\
1007 \\
388 \\
131\end{array}$ & \multicolumn{2}{|c|}{$\begin{array}{r}100 \\
124 \\
103 \\
71\end{array}$} & $\begin{array}{r}447 \\
1190 \\
547 \\
131\end{array}$ \\
\hline
\end{tabular}

* w refers to whole blood; $u$, to upper part; 1 , to lowest part. 


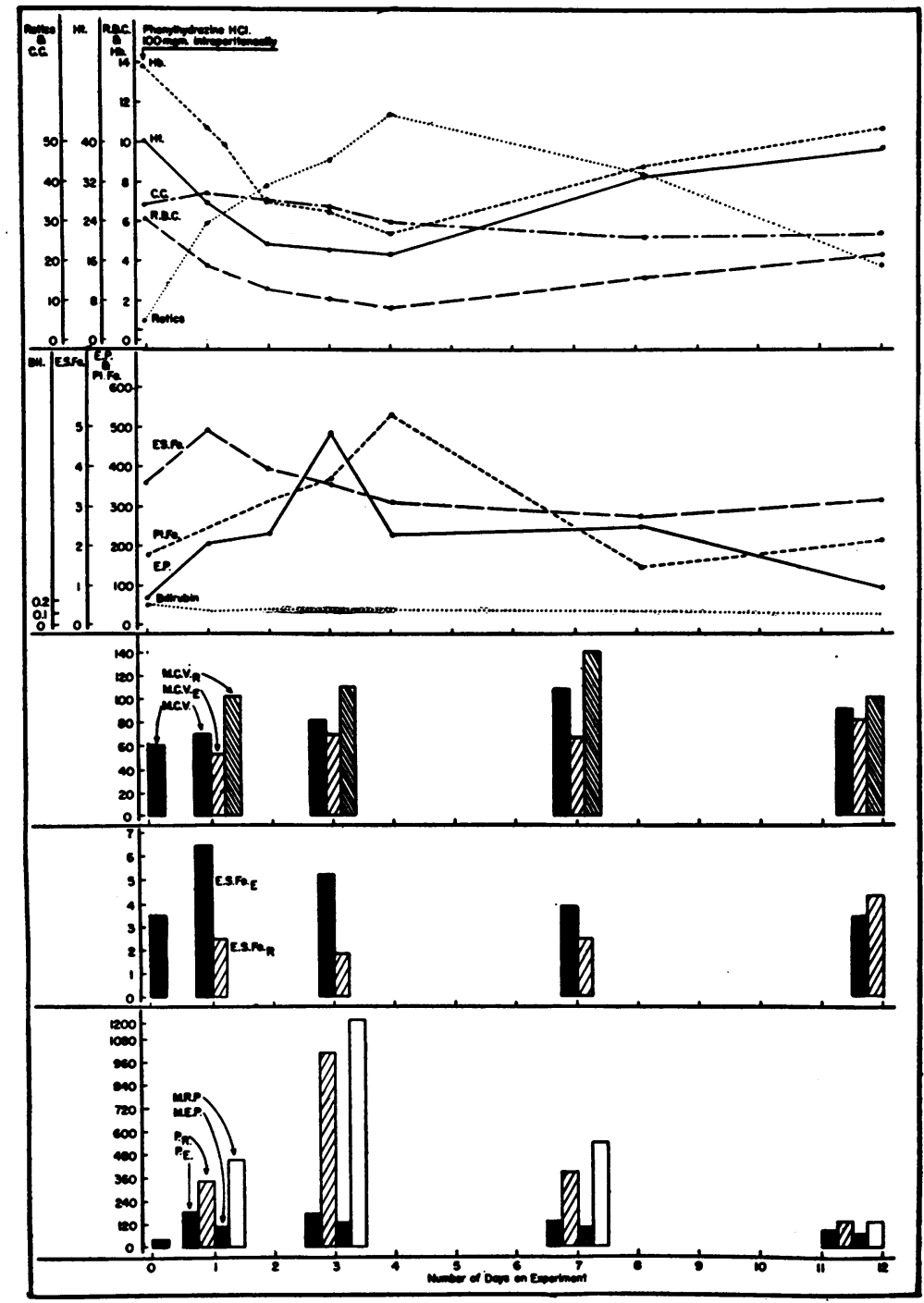

Fig. 1. Showing the Hematological and Chemical Changes in the Blood of a Rabit Following the Administration of Phenylhydrazine

Note the parallel rise of the free erythrocyte protoporphyrin (EP) and the reticulocytes following the administration of the drug and the fact that the peak of the EP rise preceded by one day the peak of the reticulocyte curve. The ESFe ("easily split-off" iron) rose within the first 24 hours and decreased at the time of maximal reticulocytosis. The content of EP in the mature red corpuscles ( $P_{E}, M E P$ ) showed practically no change. The quantity in the reticulocytes ( $P_{R}$ and $\left.M R P\right)$ was high and was greater in the reticulocytes appearing early than in those examined later. The amount of "easily split-off" iron in the mature red corpuscles (ESFe $\mathrm{E}_{\mathrm{H}}$ ) was greater than in the reticulocytes $\left(\mathrm{ESFe}_{\mathrm{R}}\right)$ except in one instance.

Explanation of Abbreviations: $\mathrm{Hb}$ refers to hemoglobin in grams per $100 \mathrm{ml}$; $\mathrm{Ht}$, volume of packed red cells in ml. per $100 \mathrm{ml}$; CC, mean corpuscular hemoglobin concentration in per cent; $\mathrm{RBC}$, red cell count in millions per c.mm.; Retics, reticulocytes in per cent; ESFe, "easily split-off" iron in mgm. per 100 mgm. of hemoglobin iron, expressed as per cent; P1.Fe. refers to plasma iron in micrograms per $100 \mathrm{ml}$. of plasma; EP, the free erythrocyte protoporphyrin in micrograms per $100 \mathrm{ml}$. of packed cells; bilirubin refers to plasma bilirubin in mgm. per 100 $\mathrm{ml}$. of plasma; $\mathrm{MCV}$ is the mean corpuscular volume of the red cells in cubic microns; $\mathrm{MCV}_{\mathrm{m}}$ is the mean corpuscular volume of the mature erythrocytes; $\mathrm{MCV}_{\mathbf{B}}$ is the mean corpuscular volume of the reticulocytes; ESFe is the "easily split-off" iron content of the mature erythrocytes; ESFe $e_{R}$ is the "easily split-off" iron content of the reticulocytes; $P_{E}$ is the micrograms of protoporphyrin in $100 \mathrm{ml}$. of packed mature erythrocytes; $P_{R}$ is the micrograms of protoporphyrin in $100 \mathrm{ml}$. of packed reticulocytes; MEP is the mean mature erythrocyte protoporphyrin expressed in micro-micromicrograms $(\mu \mu \mu \mathrm{g}$.$) ; MRP is the mean reticulocyte protoporphyrin ( \mu \mu \mu \mathrm{g}$.). 
2. Hemolytic anemia in sheep produced by the use of hemolysins:

Anti-sheep cell hemolysin was prepared by injecting washed sheep cell suspension (about 10 per cent saline suspension) intravenously into rabbits. This was done in progressively increasing amounts ranging from 0.5 to 2 ml., given every other day for a period of 30 days. At the end of this period, the rabbits' serum showed a titer of 1:500 against sheeps' cells. Two sheep were used,in this experiment.

\section{Pyridoxine deficiency anemia in pigs:}

This was produced as described by Wintrobe et al. (27).

\section{Pernicious anemia:}

The patient studied in this experiment was a man, 69 years of age, in relapse who was given pteroylglutamic acid in the amount of $50 \mathrm{mgm}$. orally per day.

\section{Splenic stasis:}

In this experiment three dogs and three pigs were used. The animals were kept under nembutal anesthesia for four hours, after which the splenic vein and artery were exposed. The spleen was seen to be greatly enlarged. A blood sample was obtained from the splenic artery and then epinephrine hydrochloride was injected directly into the organ. As soon as the spleen started to contract, a blood sample was obtained from the splenic vein. The injection of epinephrine was observed to produce a reduction in the size of the spleen to a third of its size prior to administration of the drug.

\section{RESULTS}

\section{Phenylhydrazine anemia:}

In five experiments anemia was produced in rabbits by injecting phenylhydrazine. In Table II and Figure 1 are shown the results of one of these experiments. Anemia developed rapidly following the injection of $100 \mathrm{mgm}$. of phenylhydrazine hydrochloride and reticulocytes rose promptly to reach a peak on the fourth day. The total free erythrocyte protoporphyrin (EP) began to rise promptly also but the peak was reached a day

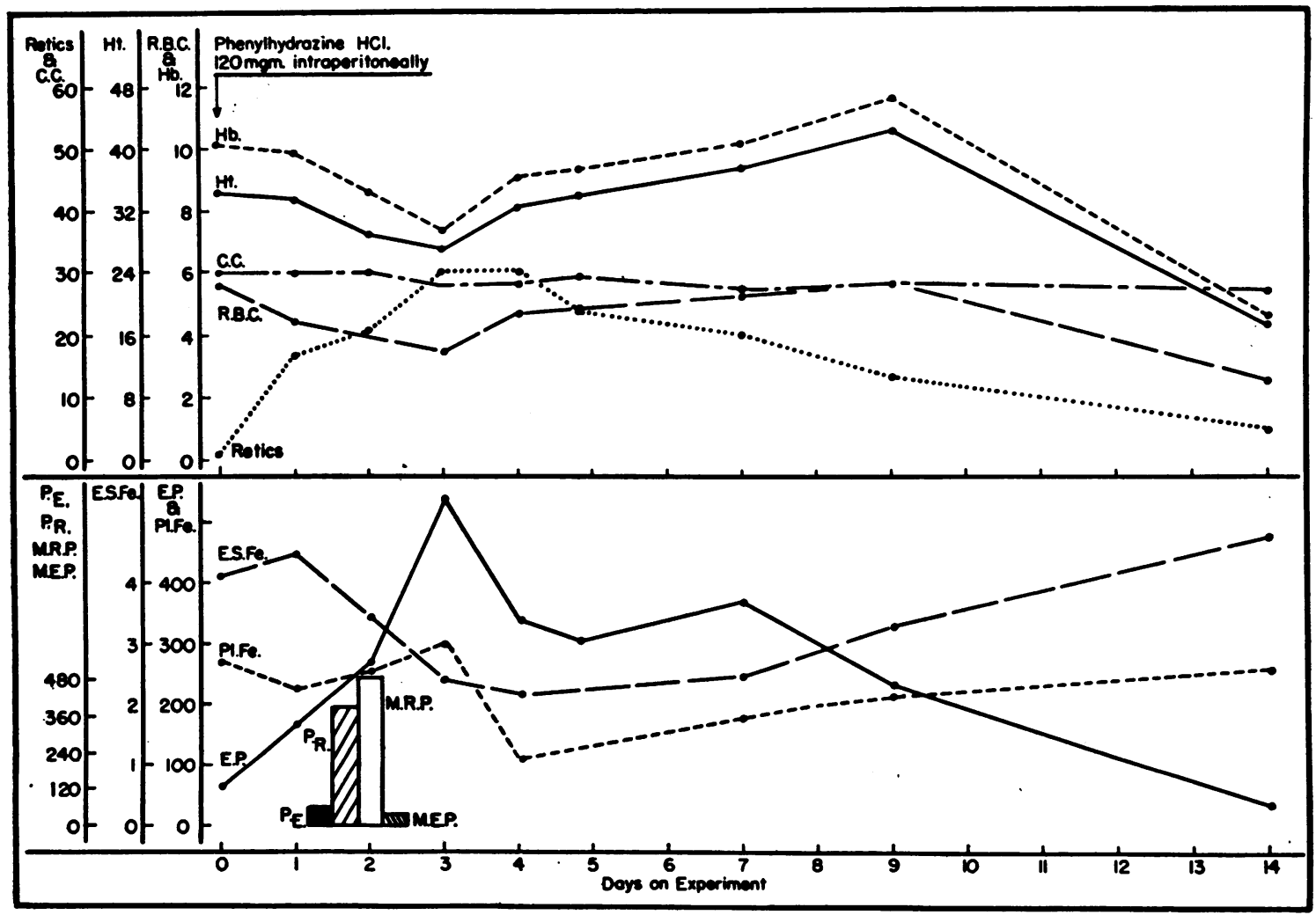

Fig. 2. Showing the Hematological and Chemical Changes in the Blood of Another Rabit Following the Administration of Phenylhydrazine

Note that the changes were similar to those shown in Figure 1, except that the peak of the EP rise was reached at the same time as the peak of the reticulocy tosis. 
earlier. The "easily split-off" iron (ESFe) rose to its highest level in 24 hours. Plasma iron increased more slowly, reaching a peak on the fourth day when the anemia was most severe. As the anemia cleared, the various values returned to normal. No significant change in plasma bilirubin was observed.

It will be noted that the mean corpuscular volume (MCV) of all the cells increased, but when the size of the mature and younger (reticulated) corpuscles was calculated, the increase was seen to be due chiefly to a great increase in the size of the reticulocytes $\left(\mathrm{MCV}_{\mathbf{R}}\right)$. Calculations of the EP content of the mature cells and the reticulo- cytes showed little change in the amount present in the former $\left(P_{E}\right)$ but a great increase in the amount found in the reticulocytes $\left(P_{R}\right)$. When these values are expressed per cell, the difference becomes more striking. Thus the mean erythrocyte protoporphyrin (MEP) ranged from 71 to 124 micro-micromicrograms whereas the content in the reticulocytes (MRP) rose from 447 to $1,190 \mu \mu \mu \mathrm{g}$., and then decreased to $131 \mu \mu \mu \mathrm{g}$. In contrast with the findings just described, the quantity of "easily split-off" iron in the mature cells $\left(\mathrm{ESFe}_{\mathrm{E}}\right)$ was much higher than in the reticulocytes $\left(\mathrm{ESFe}_{\mathbf{R}}\right)$ except in one determination. It is noteworthy that the total ESFe of the red

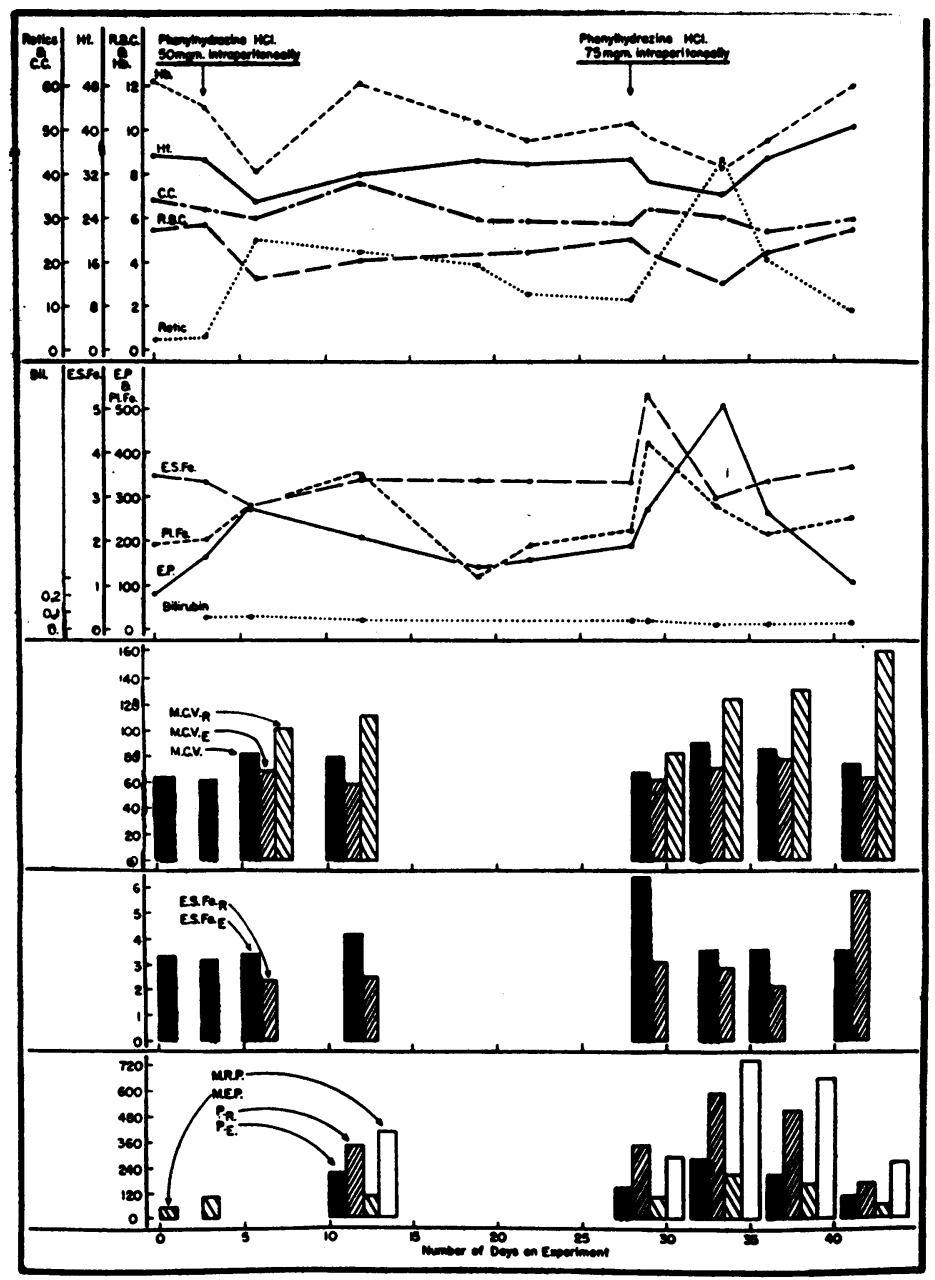

Fig. 3. Showing the Hematological and Chemical Changes in the Pooled Blood of Three Rabbits, Following Two. Successive Doses of Phenylhydrazine

Note that the changes were similar to those shown in Figures 1 and 2. 


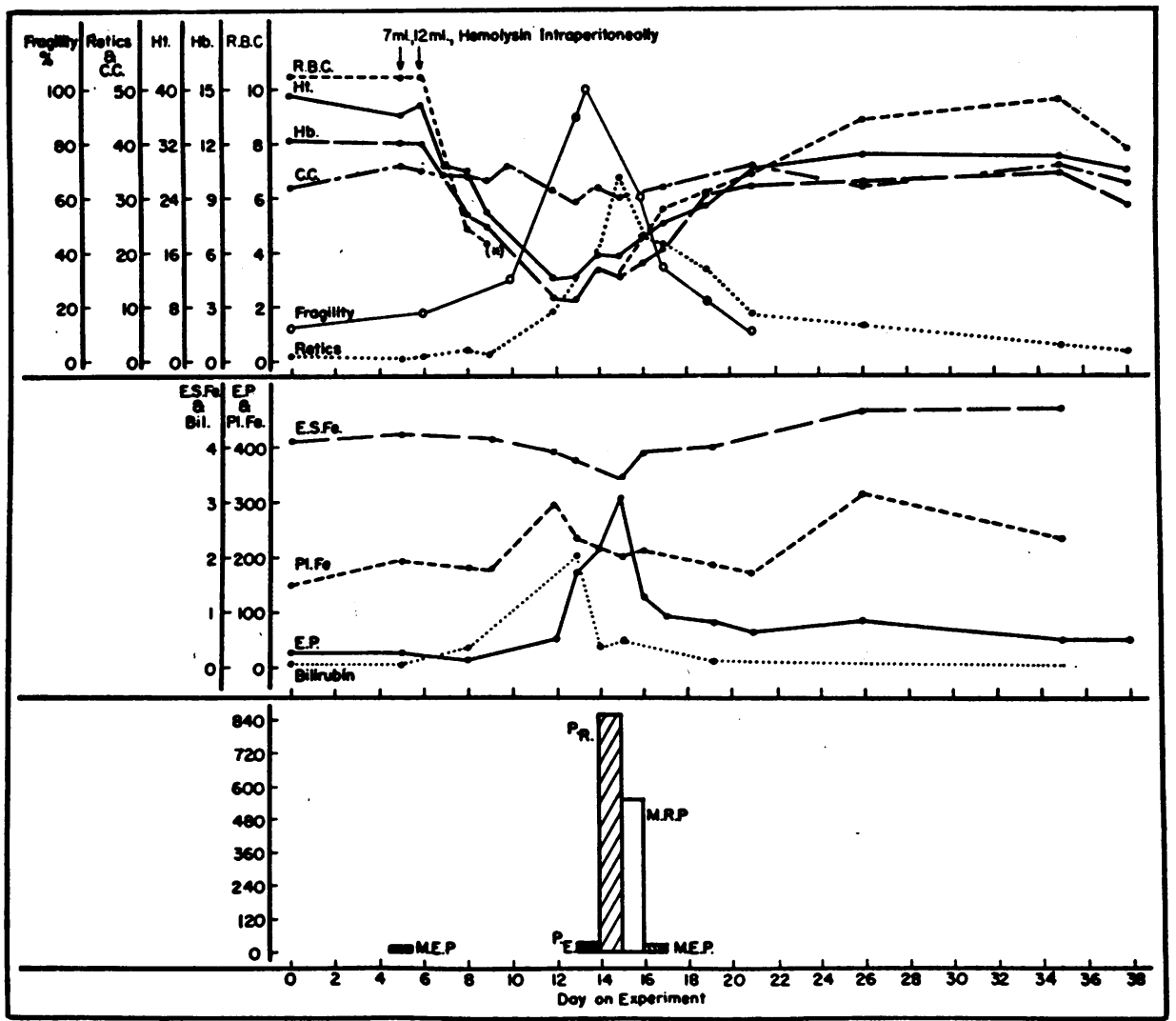

Fig. 4. Showing the Hematological and Chemical Changes in the Blood of a Sheep Following the Administration of Anti-Sheep Red Cell Hemolysin

Note that the EP did not rise during the period of greatest blood destruction but started to increase when the percentage of reticulocytes began to rise. The increase in EP and in reticulocytes were parallel, reaching a peak at the same time. The ESFe decreased at the time of maximal reticulocytosis. The MEP and $P_{\mathbf{E}}$ showed no increase but the MRP and $P_{R}$ were very high. Plasma bilirubin showed a marked increase at the time of greatest red cell fragility. The Pl.Fe. increased as blood destruction increased and rose again later.

Fragility is expressed in per cent, this representing the amount of hemoglobin in the supernatant fluid in relation to the amount in the blood prior to dilution with hypotonic saline.

cells decreased sharply prior to the peak of the reticulocytosis.

Figure 2 presents the observations in another rabbit. These were similar to those just described except that the maximal increase in total red cell EP coincided with the maximal increase in reticulocytes. It is of interest that in this animal anemia developed spontaneously after recovery had taken place. Figure 3 presents the observations in three rabbits whose blood was pooled for the various determinations. Phenylhydrazine was given these animals in two different doses, $50 \mathrm{mgm}$. and $75 \mathrm{mgm}$., respectively, the latter having been given 30 days after the former. The changes which were noted were similar to those already described. Thus the total red cell EP reached a maximum at the same time as the maximal reticulocyte response. ESFe increased sharply when 75 mgm. of phenylhydrazine were given, simultaneously with a rise in plasma iron, and then decreased prior to the rise in reticulocytes. Similar results were obtained in two more experiments but these were not completed because of the early death of the animals.

\section{Hemolytic anemia in sheep:}

The data obtained in sheep No. 1 are shown in Figure 4. Two doses (7 and $12 \mathrm{ml}$.) of anti-sheep cell hemolysin were given intraperitoneally. Anemia developed very rapidly, reaching the most 
severe stage on the seventh day. At this time the red blood cells were so agglutinated that a count could not be done with Hayem's solution. This difficulty was overcome by using Gower's solution (19). The hypotonic saline fragility of the erythrocytes was maximal at the time when the anemia was most severe and the plasma bilirubin increased simultaneously. An increase of reticulocytes commenced on the fourth day, when the anemia was already quite severe. The reticulocytosis reached its peak at the tenth day after the first injection of hemolysin. It will be noted that the EP did not rise; in fact it decreased slightly at the time of the greatest red cell degradation. As in the phenylhydrazine anemia, however, the EP rose when the reticulocytes increased, the peak corresponding to the highest reticulocytosis. The only significant change in the ESFe was a drop in this value at the time of the peak of the reticulocytosis. The plasma iron first showed an increase coinciding with the time of most severe anemia and greatest blood destruction as indicated by increased red cell fragility and plasma bilirubinemia. A second rise in plasma iron developed at the time when the blood was approaching normal.

From the calculated data, it may be seen that the MEP and $\mathrm{P}_{\mathrm{E}}$ did not show a significant change at the time of the greatest red cell destruction. The MRP and $P_{R}$, on the other hand, were very high as was found in phenylhydrazine anemia.

The results of the experiment in sheep No. 2 are shown in Figure 5. This animal was given $5 \mathrm{ml}$. anti-sheep cell rabbit serum intraperitoneally on three successive days. It may be seen that the results are similar to those in sheep No. 1 except

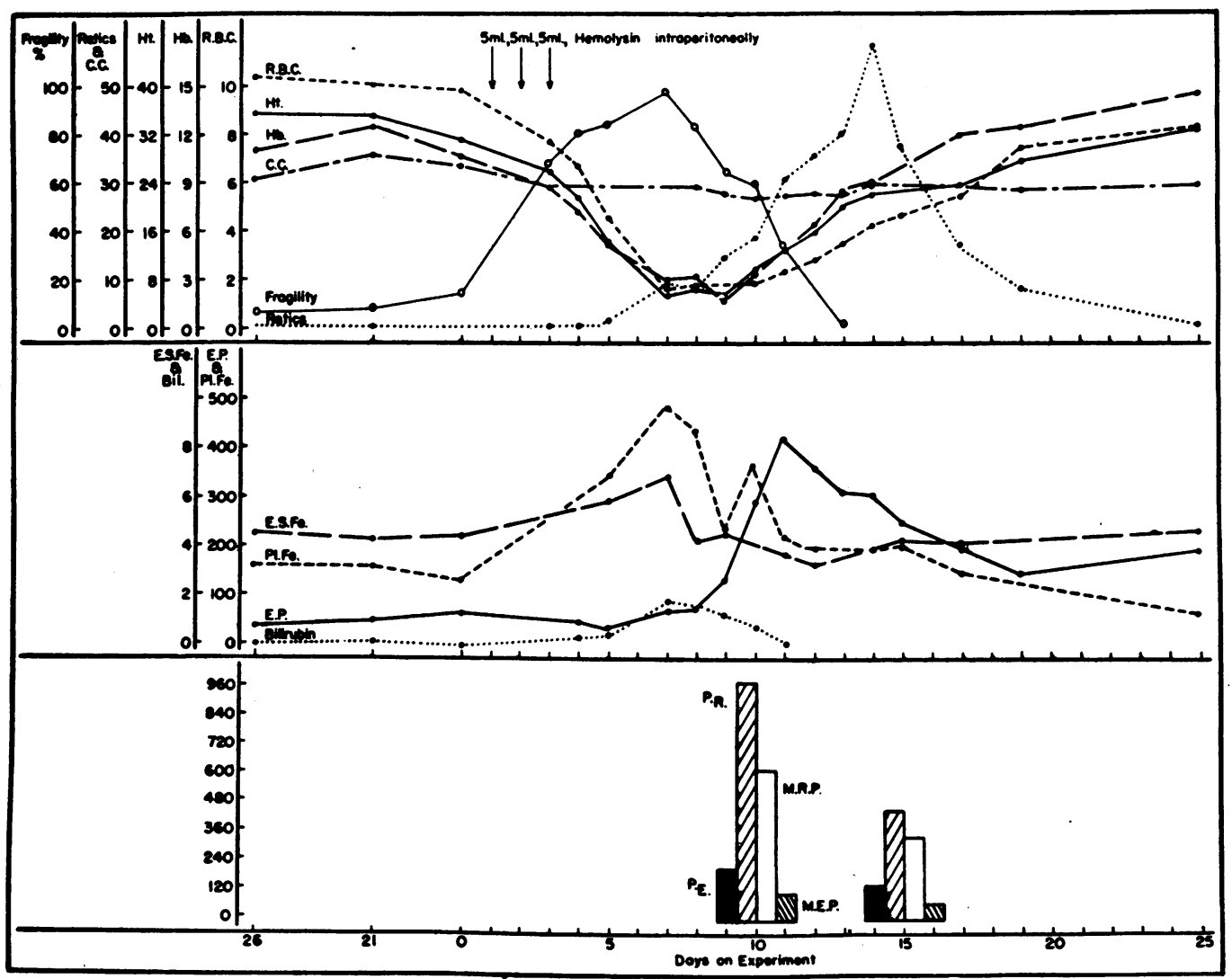

Fig. 5. Showing the Changes in the Blood of Another Sheep Following the Administration of Anti-Sheep Red Cell Hemolysin

Note that the changes which followed were like those shown in Figure 4 except that the peak of the rise in EP preceded by one day the peak of the increase in reticulocytes and the ESFe increased at the time of the greatest red blood cell destruction. 


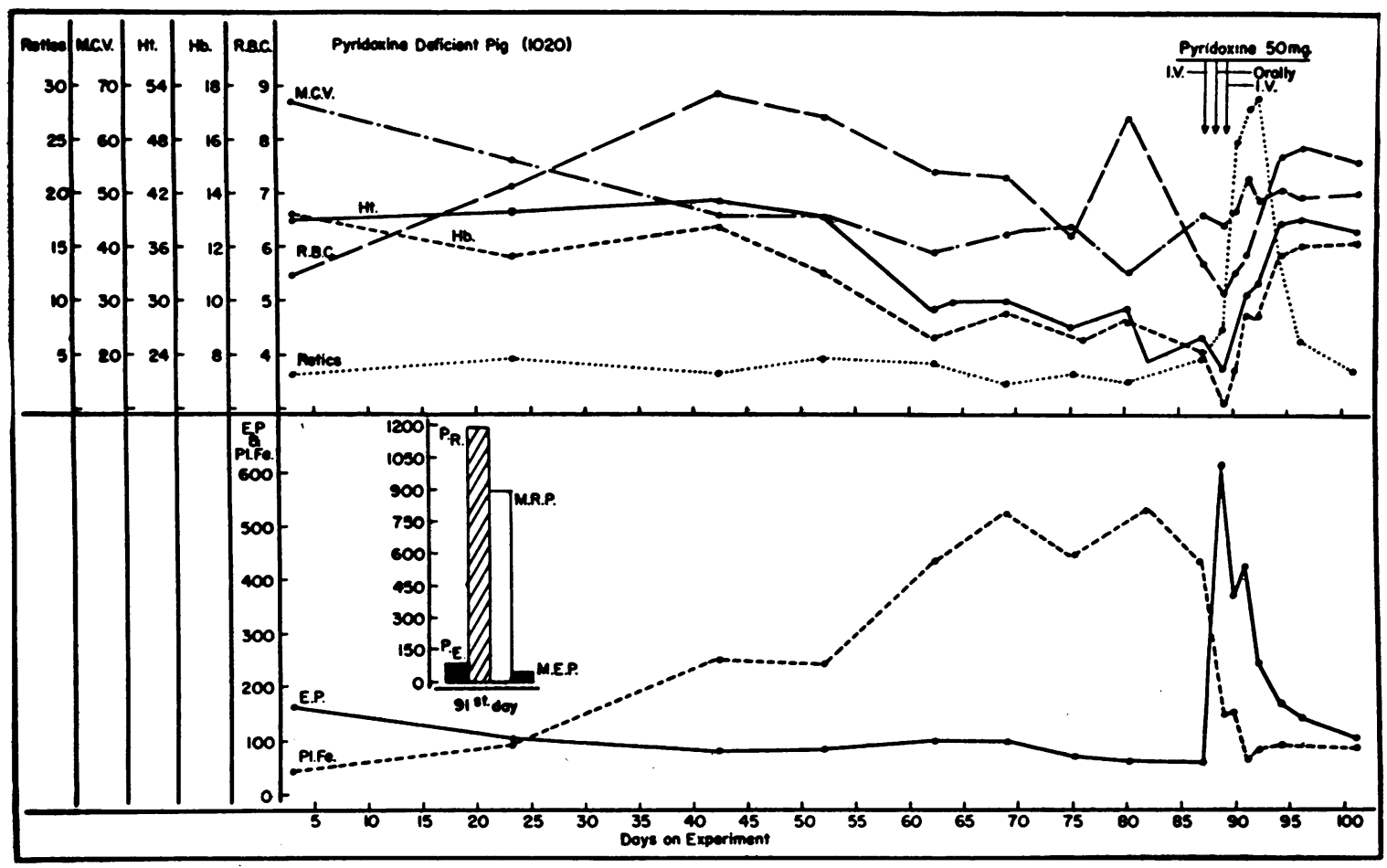

Fig. 6. Showing the Hematological and Chemical Changes in the Blood of a Pyridoxine-Deficient Pig and the Effects Produced by Administration of Pyridoxine

The anemia started to develop about the 52nd day following the commencement of the pyridoxine-deficient diet. This was accompanied by a decrease in the volume of the red corpuscles (MCV) and in EP as well as a great increase in the plasma iron. After treatment, there was a very marked rise in EP 48 hours following the first dose of pyridoxine which coincided with a rise in the percentage of reticulocytes, a sharp drop in the plasma iron content and an increase in the size of the red blood cells.

for the following: the peak of the EP curve was reached earlier than the peak of the reticulocyte curve and the EP persisted at an unusually high value in spite of a marked fall in the reticulocyte percentage.

\section{Pyridoxine deficiency anemia in pigs:}

Pyridoxine deficiency anemia developed in two pigs, $10-20$ and 10-21. The data obtained in pig 10-20 are shown in Figure 6. It may be seen that anemia started to develop on the 52nd day following commencement of the pyridoxine-deficient diet. This was accompanied by a drop in the MCV, an increase in the plasma iron and a decrease in EP to an abnormally low level. 'The decrease in EP in pyridoxine deficiency confirms earlier observations in this laboratory (28).

These changes were most pronounced on the 82nd day after the start of the diet. After treatment with pyridoxine the reticulocytes increased sharply, reaching a maximal value on the fifth day after the first injection was given. This was followed by an increase in the volume of packed red cells and in the size of red corpuscles. A striking change took place in the EP level. On the second day after $50 \mathrm{mgm}$. pyridoxine was given intravenously, the EP increased from 60 to 612 $\mu \mathrm{g}$. per $100 \mathrm{ml}$. red cells. The normal value for $\mathrm{EP}$ in the pig is approximately $100 \mu \mathrm{g}$. The EP level then dropped in spite of an increase in the reticulocyte percentage. The plasma iron dropped also on the second day after treatment to a normal level and continued at that level.

The calculated data for protoporphyrin in the reticulocytes and mature cells (MRP, MEP, $P_{\mathbf{R}}$, $\left.P_{E}\right)$ in this animal showed much higher values in the immature cells, just as was observed in the experimental anemias already described.

Pig 10-21 developed anemia with similar chemical abnormalities. Although the anemia was not 
TABLE III

Pyridoxine-deficient pig (10-21)

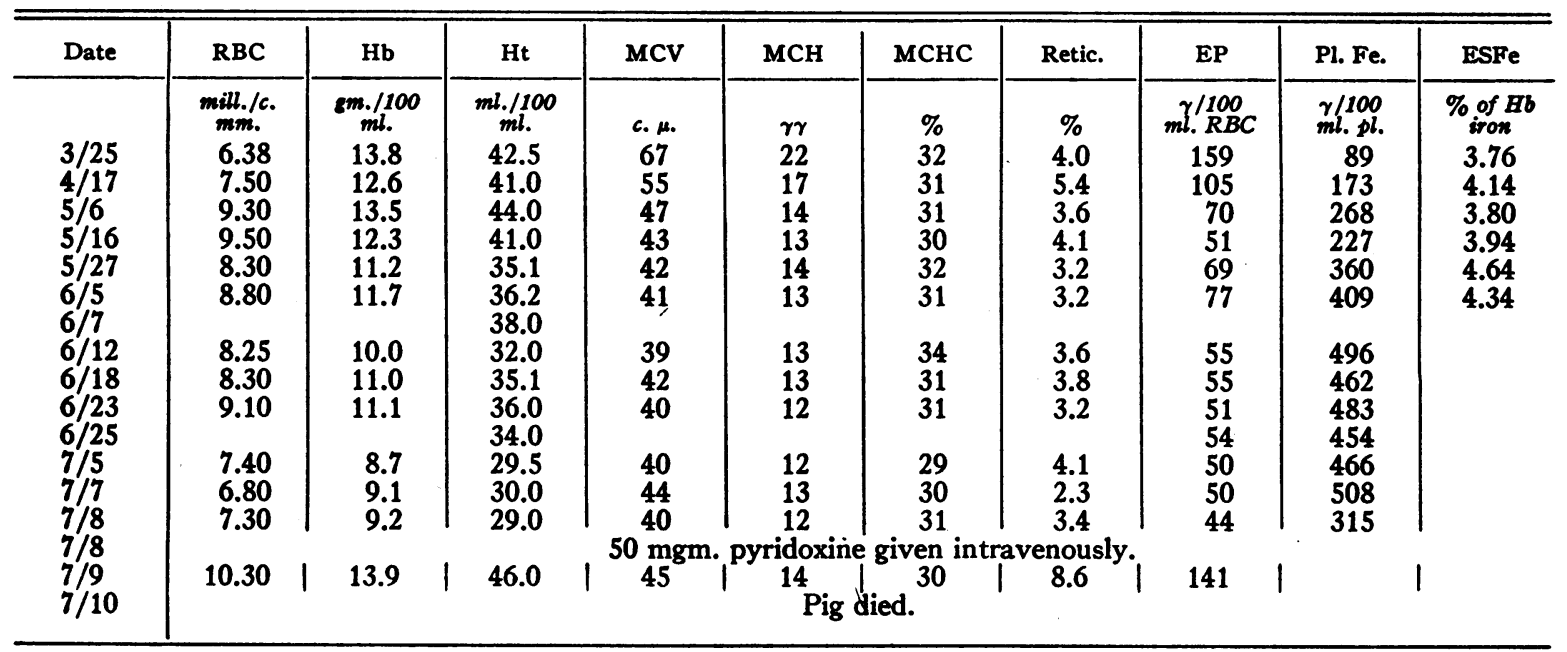

as severe as in $10-20$, the chemical changes were even more pronounced (Table III). The deficiency in this animal was so severe that, in spite of treatment, the animal died.

\section{Pernicious anemia:}

The results in a case of pernicious anemia treated with pteroylglutamic acid are shown in Figure 7. The peak of the rise in EP was reached

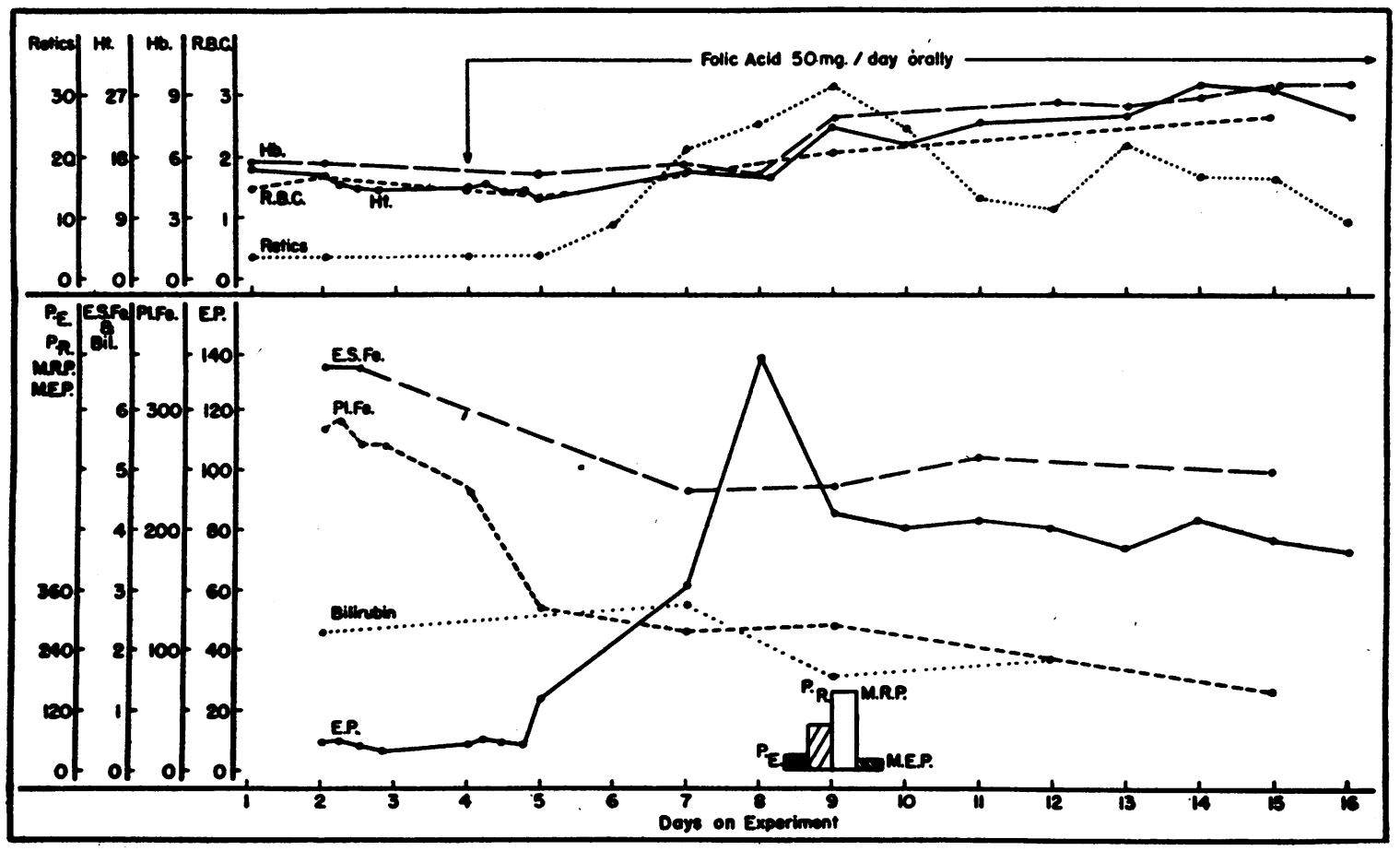

Fig. 7. Showing the Hematological and Chemical Changes in the Blood of a Patirnt with Pernicious Anemia in Relapse, Following Treatment with Pteroylglutamic Acid

Note the consistently low EP at different hours of the day prior to therapy and the increase after treatment which coincided with the rise of the reticulocyte percentage; the peak of the EP level preceded by one day the peak of the reticulocytosis. P1.Fe, ESFe, and bilirubin dropped after treatment. $P_{\mathrm{B}}$ and MRP were very much higher than the $P_{1}$ and MEP. 


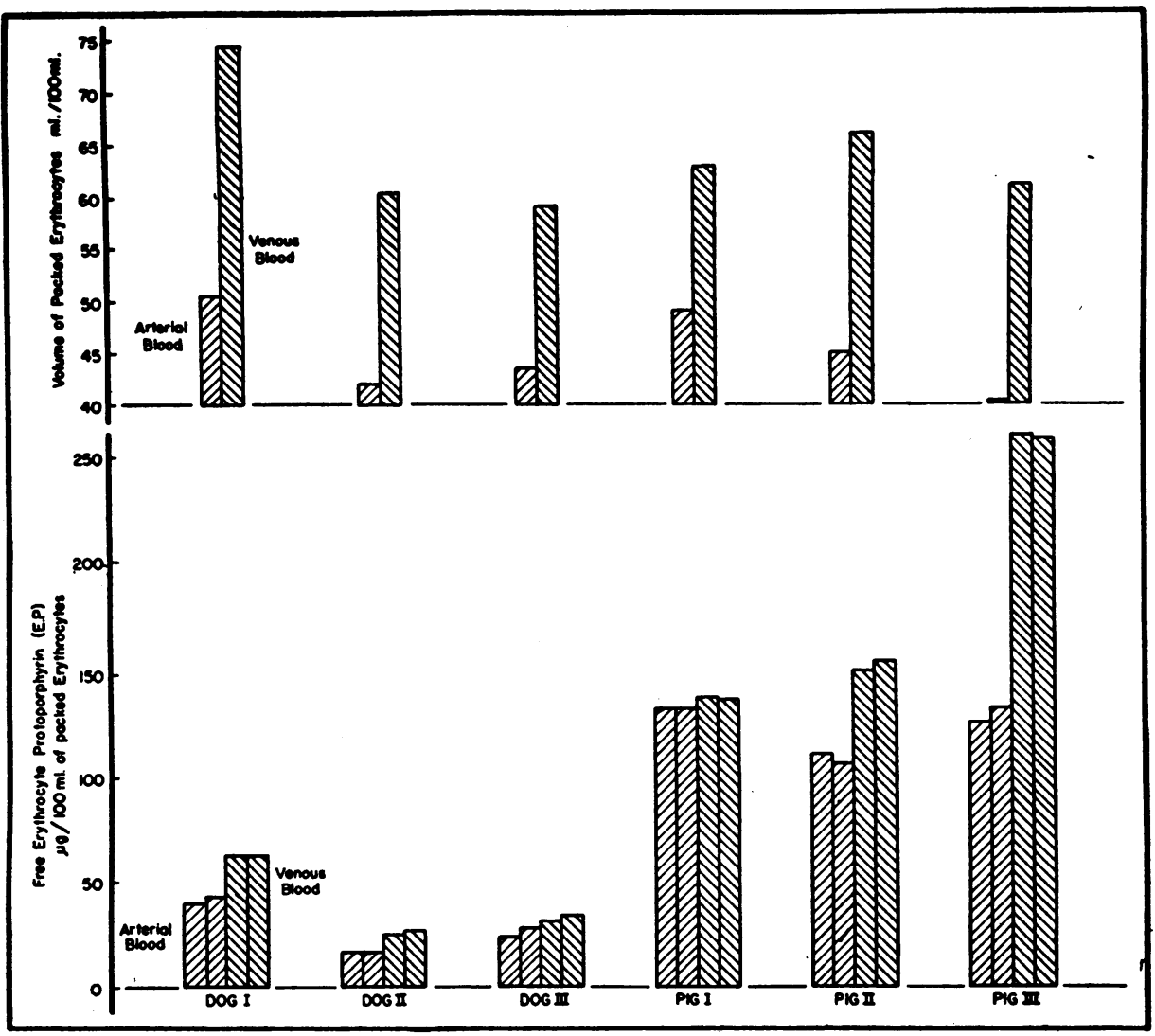

Fig. 8. Showing the Concentration of the Venous Blood from the Spleen After Stasis During Nembutal Anesthesia in Three Dogs and Three Pigs, and the InCREASE IN EP Associated with Stasis

The EP determinations were done in duplicate and are so shown.

one day earlier than the peak of the reticulocyte curve. The ESFe dropped as the reticulocytes increased. Plasma iron and bilirubin decreased at the same time. The MEP and $\mathrm{P}_{\mathrm{E}}$ showed no significant change after treatment; the MRP and $P_{R}$ were high, just as had been found in the experimentally induced hemolytic anemias. The very low values for EP during relapse are of interest. These were observed to be constantly low during the different hours of the day.

\section{Splenic stasis:}

The effect of stasis was studied in order to see whether the increased EP observed by Watson et al. (4) during in vitro sterile incubation of blood takes place also in blood sequestrated for some time in the spleen. The data obtained in this experiment are presented in Figure 8 and Table III. It can be seen that there was a marked hemocon- centration of the venous blood of the spleen as compared with the arterial blood. This is in accord with the findings of previous workers $(29,30)$. The EP was significantly higher in the venous blood from the spleen. As may be seen in Figure 8, the difference between the splenic venous and arterial EP content was always significantly greater than the difference between duplicate samples of the same blood. On the other hand, the EP content of the jugular vein blood taken prior to the administration of nembutal was the same as that of arterial blood after nembutal. It may be seen in Table IV that, except in dog No. 2 , the values for ESFe in red cells from arterial blood were higher than in those from venous blood.

\section{DISCUSSION}

In these studies it was found that the free protoporphyrin of the erythrocytes (EP) rose simul- 
TABLE IV

Effect of splenic stasis

\begin{tabular}{|c|c|c|c|c|c|c|c|c|c|c|c|}
\hline & $\underset{\substack{\mathrm{Hb} \\
\text { art. }}}{\mathrm{Hb}}$ & $\underset{\text { ven. }}{\text { Hb }}$ & $\underset{\text { art. }}{\mathrm{Ht}}$ & $\underset{\text { ven. }}{\mathrm{Ht}}$ & $\begin{array}{c}\text { Retics. } \\
\text { art. }\end{array}$ & $\begin{array}{l}\text { Retics. } \\
\text { ven. }\end{array}$ & $\mid \begin{array}{c}\text { tEP\# } \\
\text { jug. vein }\end{array}$ & $\begin{array}{l}\text { †EP* } \\
\text { art. }\end{array}$ & $\begin{array}{l} \pm E P * \\
\text { ven. }\end{array}$ & $\begin{array}{l}\text { ESFe } \\
\text { art. }\end{array}$ & $\begin{array}{l}\text { ESFe } \\
\text { ven. }\end{array}$ \\
\hline Dog I & $\begin{array}{c}g m . \\
17.20\end{array}$ & $\begin{array}{c}g m . \\
24.18\end{array}$ & $\begin{array}{c}m l . \\
50.5\end{array}$ & $\begin{array}{c}m l . \\
74.2\end{array}$ & $\begin{array}{c}\% \\
2.3\end{array}$ & $\begin{array}{c}\% \\
3.0\end{array}$ & $\begin{array}{l}\text { ug./100 ml. } \\
\text { packed cells }\end{array}$ & $\begin{array}{l}\text { Mg. } 1100 \mathrm{ml} \text {. } \\
\text { packed cells } \\
40 \\
43\end{array}$ & \begin{tabular}{|c} 
Mg. $/ 100 \mathrm{ml}$ \\
packed cells \\
63.5 \\
63.5
\end{tabular} & $\begin{array}{c}\begin{array}{c}\% \text { of } \\
\text { Hb iron }\end{array} \\
5.35 \\
5.35\end{array}$ & $\begin{array}{c}\text { \% of } \\
\text { Hb iron } \\
5.38 \\
5.17\end{array}$ \\
\hline Dog II & 14.63 & 21.00 & 42.0 & 60.3 & - & - & 17 & $\begin{array}{l}16 \\
16\end{array}$ & $\begin{array}{l}25 \\
27\end{array}$ & 5.16 & 5.26 \\
\hline Dog III & 13.93 & 19.79 & 43.5 & 59.0 & 0.8 & 1.2 & & $\begin{array}{l}24.9 \\
25.3\end{array}$ & $\begin{array}{l}31.6 \\
33.0\end{array}$ & 5.73 & 5.36 \\
\hline Pig I & 16.50 & 22.25 & 49.0 & 63.0 & 1.3 & 2.0 & 127 & $\begin{array}{l}134 \\
134\end{array}$ & $\begin{array}{l}138.0 \\
137.5\end{array}$ & $\begin{array}{l}3.06 \\
3.20\end{array}$ & $\begin{array}{l}2.99 \\
3.02\end{array}$ \\
\hline Pig II & 15.37 & 22.23 & 45.0 & 66.0 & 0.5 & 2.5 & 107 & $\begin{array}{l}111 \\
107\end{array}$ & $\begin{array}{l}152 \\
156\end{array}$ & $\begin{array}{l}2.98 \\
2.98\end{array}$ & $\begin{array}{l}2.73 \\
2.68\end{array}$ \\
\hline Pig III & 13.76 & 19.92 & 40.1 & 61.0 & 3.3 & 4.9 & 133 & $\begin{array}{l}126 \\
129\end{array}$ & $\begin{array}{l}260 \\
258\end{array}$ & $\begin{array}{l}2.87 \\
3.04\end{array}$ & $\begin{array}{l}2.62 \\
2.63\end{array}$ \\
\hline
\end{tabular}

$\dagger E P \#$ The free erythrocyte protoporphyrin of the blood from the jugular vein taken before the administration of nembutal.

$\ddagger E P^{*}$ The free erythrocyte protoporphyrin of the arterial and venous blood after nembutal anesthesia. The determinations were made in duplicate and are so recorded.

taneously with or just prior to the increase in reticulocytes which developed following the administration of phenylhydrazine to rabbits, hemolysin to sheep, pyridoxine to pyridoxine-deficient pigs or folic acid to a patient with pernicious anemia in relapse. In no instance did an increase in EP occur following the rise in reticulocytes. When the content of free erythrocyte protoporphyrin $\left(P_{R}, M R P\right)$ in the reticulocytes was compared with that in mature cells $\left(P_{E}, M E P\right)$ the values were found to be strikingly and consistently higher in the immature forms. When the EP of red cells coming from the spleen following stasis was measured, it was found to be greater than that of cells from arterial blood. However, in the experimental anemias the EP did not rise when blood destruction was very great, increasing instead, as above noted, when young cells made their appearance.

These findings are consistent with those of Watson and his associates $(4,6)$, DeLangen and Grotepass (7) and Seggel (5), already cited, as well as with those of Stasney (31) who found the protoporphyrin content of the bone marrow to be increased when the percentage of normoblasts was increased. They support the suggestion that the free erythrocyte protoporphyrin represents porphyrin which is awaiting utilization for hemoglobin formation. It is of interest in this connection that, not only was the mean reticulocyte content of protoporphyrin (MRP) higher than that of mature red corpuscles (MEP), but in a number of experiments the content in the reticulocytes which appeared at first was greater than in those appearing later (see Figures 1, 3 and 5). It might be expected that, in the reticulocytes appearing early in response to some stimulus, hemoglobin synthesis would not be as complete as in those which appeared when the crisis had become less acute.

It does not follow, however, that the presence of a high EP necessarily signifies the presence of a great number of immature cells. It would seem more correct to say, in the present state of our knowledge, that a high EP is indicative of uncompleted hemoglobin synthesis. The high EP found in iron-deficiency anemia $(5,8)$ may represent protoporphyrin which has not been formed into hemoglobin due to lack of iron; the high values observed in lead $(4,5,32)$ and in gold (4) intoxication may represent a failure in hemoglobin synthesis due to chemical interference by these heavy metals. Finally the high EP observed in our laboratory (1) in cases of anemia associated with infection may be explained by assuming that there is a failure to utilize protoporphyrin completely for 
hemoglobin synthesis. That there is failure in such cases of anemia to use iron in the normal fashion for this purpose has been shown by us already $(33)$.

It seems possible also that under certain circumstances the free protoporphyrin in the erythrocytes may rise as the result of intracorpuscular degradation of hemoglobin. The increase of EP following stasis of red corpuscles in the spleen, which we have observed, is similar to the increase noted by Watson et al. (4) in vitro and could be attributed to red cell degradation. Such an increase in EP could also be explained, however, by assuming that following splenic stasis a greater proportion of younger cells, containing more EP, remains, the oldest forms having been destroyed in the spleen. This thesis is consistent with the observation that the ESFe was lower in the venous blood than in arterial, but is not supported by the finding of a significantly increased percentage of reticulocytes in the blood from the splenic vein. Yet it is noteworthy that the hemolytic anemias produced in our experiments were not accompanied by a rise in EP at the time when red cell destruction was greatest.

We are at a loss to explain the discrepancy between our observations in pernicious anemia and those of Seggel (5) and of Watson et al. (4) who found the maximal increase in EP to follow rather than to coincide with or precede the maximal increase in reticulocytes. In phenylhydrazine anemia Watson et al. (4) observed a parallel increase in EP and reticulocytes. An increase in EP one day prior to the rise in reticulocytes, as we have observed in some instances, might have been missed by Watson et al. since their measurements were made at intervals of two or three days instead of daily. Speculation is unwarranted, however, until further studies are made to clarify this point.

With regard to the significance of the "easily split-off" iron (ESFe), it should be pointed out that (1) the ESFe increased within 24 hours following the injection of phenylhydrazine; (2) this increase coincided in one instance (Figure 5) with a rise in plasma iron, erythrocyte fragility and plasma bilirubin following the injection of hemolysin in one sheep but in another animal no increase was observed; (3) ESFe decreased at the time of maximal increase of reticulocytes; and
(4) the quantity in mature corpuscles $\left(\mathrm{ESFe}_{\mathrm{E}}\right)$ was greater than in reticulocytes $\left(\mathrm{ESFe}_{\mathbf{R}}\right)$. These observations suggest that ESFe is a degradation product of hemoglobin associated with destruction, maturation and perhaps senescence of red corpuscles.

The variations in plasma iron observed in our studies correspond to those described by others (34). An increase in plasma iron may result from its release from hemoglobin during blood destruction; rapid blood formation, however, leads to an increased demand for iron which in turn tends to deplete the amount in the plasma.

\section{SUMMARY}

1. The free protoporphyrin of the erythrocytes (EP) as well as the "easily split-off" iron (ESFe) were measured in reticulocytes and in mature cells taken from the blood of (1) rabbits in which anemia was produced by giving phenylhydrazine; (2) sheep in which anemia was caused by injecting anti-sheep red cell hemolysin; (3) pigs in which pyridoxine deficiency anemia was produced and subsequently treated; (4) dogs and pigs in which splenic stasis was induced; and (5) a human subject with pernicious anemia treated with pteroylglutamic acid.

2. It was found that the EP increased and reached a maximal level simultaneously with or just prior to the reticulocytosis observed in these conditions. The EP did not increase in the hemolytic anemias when the blood destruction was maximal. The content of EP was very much greater in reticulocytes than in mature red corpuscles. An increase in EP was also observed in the red cells taken from the splenic vein following stasis.

3. The ESFe increased in the first 24 hours following the injection of phenylhydrazine and then decreased at the time of maximal increase of reticulocytes. The content of ESFe in reticulocytes was less than in mature corpuscles.

4. These observations are interpreted as indicating that $(a)$ an increase in EP usually signifies uncompleted hemoglobin synthesis which may be the consequence of the liberation of immature cells or is due to iron deficiency, toxic factors or other causes. An increase in EP may possibly also result from hemoglobin degradation; and 
(b) the ESFe is a degradation product of hemoglobin associated with destruction, maturation and perhaps senescence of red corpuscles.

\section{BIBLIOGRAPHY}

1. Cartwright, G. E., Lauritsen, M. A., Jones, P. J., Merrill, I. M., and Wintrobe, M. M., The anemia of infection. I. Hypoferremia, hypercupremia, and alterations in porphyrin metabolism in patients. J. Clin. Invest., 1946, 25, 65.

2. Van den Bergh, A. A. H., and Hyman, A. J., Studien über Porphyrin. Deutsche med. Wchnschr., 1928, 54, 1492.

3. Grotepass, W., Het porphyrine in normale bloedlichaampjes. Nederl. Tijdschr. v. Geneesk., 1937, 81, 362.

4. Watson, C. J., Grinstein, M., and Hawkinson, V., Studies of protoporphyrin. IV. A comparison of the erythrocyte protoporphyrin concentration with the reticulocyte percentage under experimental and clinical conditions. J. Clin. Invest., 1944, 23, 69.

5. Seggel, K. A., Fluoreszenphänomen und Porphyringehalt der Erythrocyten. Ergebn. inn. Med. u. Kinderh., 1940, 58, 582.

6. Watson, C. J., and Clarke, W. O., The occurrence of protoporphyrin in the reticulocytes. Proc. Soc. Exper. Biol. \& Med., 1937, 36, 65.

7. De Langen, C. D., and Grotepass, W., Zur Frage des Porphyrinstoffwechsel beim Auf- und Abbau des Blutes. Acta Med. Scandinav., 1938, 94, 245.

8. Watson, C. J., Some newer concepts of the natural derivatives of hemoglobin; general considerations; serum bilirubin and bilirubinuria; erythrocyte protoporphyrin. Blood, 1946, 1, 99.

9. Czike, A., Über Gallenfarbstoffbildung in vitro. Deutsch. Arch. f. klin. Med., 1929, 164, 236.

10. Barkan, G., and Walker, B. S., The red blood cell as a source of the iron and bilirubin of the blood plasma. J. Biol. Chem., 1939, 131, 447.

11. Watson, C. J., and Paine, J. R., A study of the splenic venous blood, with particular reference to the hematocrit percentage and the hemoglobin concentration of the erythrocytes before and after splenic arterial injection of adrenalin. Tr. A. Am. Physicians, 1942, 57, 249. Am. J. M. Sc., 1943, 205, 493.

12. Barkan, G., and Schales, O., Chemischer Aufbau und physiologische Bedeutung des "leicht abspaltbaren" Bluteisens. 13. Mitteilung in der Reihe der Eisentudien. Ztschr. f. physiol. Chem., 1937, 248, 96.

13. Legge, J. W., and Lemberg, R., Coupled oxidation of ascorbic acid and haemoglobin; the "labile iron" in blood and its increase during choleglobin formation. Biochem. J., 1941, 35, 353.

14. Lemberg, R., Lochwood, W. H., and Legge, J. W., Coupled oxidation of ascorbic acid and hemoglobin; studies on the formation of bile pigments from choleglobin and verdohaemochromogen and on their isolation from erythrocytes. Biochem. J., 1941, 35, 363.

15. Moore, C. V., Arrowsmith, W. M. R., Quiligan, J. J., Jr., and Read, J. T., Studies in iron transportation and metabolism. I. Chemical methods and normal values for plasma iron and "easily split-off" blood iron. J. Clin. Invest., 1937, 16, 613.

16. Venndt, H., Ztschr. f. physiol. Chem., 1940, 236, 613. Quoted by G. Barkan and O. Schales, Proc. Soc. Exper. Biol. \& Med., 1942, 50, 74.

17. Miller, L. L., and Hahn, P. F., The appearance of radioactive iron as hemoglobin in the red cell. The significance of "easily split-off" iron. J. Biol. Chem., 1940, 134, 585.

18. Key, J. A., Studies on erythrocytes with special refence to reticulum, polychromatophilia and mitochondria. Arch. Int. Med., 1921, 28, 511.

19. Wintrobe, M. M., Clinical Hematology. Lea and Febiger, Philadelphia, 1946, Ed. 2.

20. Clegg, J. W., and King, E. J., Estimation of haemoglobin by alkaline haematin method. Brit. M. J., 1942, 2, 329.

21. Hunter, F., A photoelectric method for the quantitative determination of erythrocyte fragility. J. Clin. Invest., 1940, 19, 691.

22. Barkan, G., and Walker, B. S., Determination of serum iron and pseudohemoglobin iron with $\mathrm{O}$ phenanthroline. J. Biol. Chem., 1940, 135, 37.

23. Ducci, H., and Watson, C. J., The quantitative determination of serum bilirubin with special reference to the prompt-reacting and the chloroform-soluble types. J. Lab. \& Clin. Med., 1945, 30, 293.

24. Barkan, G., and Walker, B. S., Differentiation of red blood cells by their pseudohemoglobin content. J. Biol. Chem., 1940, 135, 803.

25. Grinstein, M., and Watson, C. J., Studies of protoporphyrin. III. Photoelectric and fluorophotometric methods for the quantitative determination of the protoporphyrin in blood. J. Biol. Chem., 1943, $147,675$.

26. Grinstein, M., and Wintrobe, M. M., Spectrophotometric micromethod for the quantitative determination of the free erythrocyte protoporphyrin. J. Biol. Chem., 1948, 172, 459.

27. Wintrobe, M. M., Follis, R. H., Jr., Miller, M. H., Stein, H. J., Alcayaga, R., Humphreys, S., Suksta, A., and Cartwright, G. E., Pyridoxine deficiency in swine; with particular reference to anemia, epileptiform convulsions and fatty liver. Bull. Johns Hopkins Hosp., 1943, 72, 1.

28. Cartwright, G. E., and Wintrobe, M. M., Studies on free erythrocyte protoporphyrin, plasma copper and plasma iron in normal and in pyridoxine-deficient swine. J. Biol. Chem., 1948, 172, 557.

29. Ham, T. H., and Castle, W. B., Mechanism of hemolysis in certain anemias. Significance of increased hypotonic fragility and of erythrostasis. J. Clin. Invest., 1940, 19, 788. 
30. Wakim, R. G., Effects of adrenalin and nembutal anesthesia on blood constituents before and after splenectomy. J. Lab. \& Clin. Med., 1946, 21, 18.

31. Stasney, J., and McCord, W. M., Serial bone marrow studies in pernicious anemia. III. Occurrence of protoporphyrin in human bone marrow. Proc. Soc. Exper. Biol. \& Med., 1943, 51, 340.

32. Vigliani, E. C., Angeleri, C., and Sano, M., Nuovi studi sul metabolismo delle porfirine nell' intossicazione da piombo. Arch. per le sc. med., 1938, $65,423$.
33. Wintrobe, M. M., Greenberg, G. R., Humphreys, S. R., Ashenbrucker, H., Worth, W., and Kramer, R., The anemia of infection. III. The uptake of radioactive iron in iron-deficient and in pyridoxinedeficient pigs before and after acute inflammation. J. Clin. Invest., 1947, 26, 103.

34. Moore, C. V., Doan, C. A., and Arrowsmith, W. R., Studies in iron transportation and metabolism. II. Mechanism of iron transporation: its significance in iron utilization in anemic states of varied etiology. J. Clin. Invest., 1937, 16, 627. 